\title{
PENGARUH PERBANDINGAN SARI EDAMAME (Glycin Max L. Merrill) DENGAN SARI BLACK MULBERRY (Morus nigra L.) DAN KONSENTRASI PENSTABIL TERHADAP KARAKTERISTIK MINUMAN EDAMUBERRY
}

\author{
Asep Dedy Sutrisno, Yusman Taufik, Willy Pranata Wijaya, Della Ratna Komala \\ Program Studi Teknologi Pangan, Fakultas Teknik, Universitas Pasundan, Jl. Dr.Setiabudi No 93, Bandung, 40153, \\ Indonesia \\ E-mail : yusmantaufik@unpas.ac.id
}

Diterima pertama kali: 12 Januari 2020, Direvisi: 13 Januari 2020, Disetujui untuk publikasi: 16 Januari 2020

\begin{abstract}
The purpose of this research was to determine the effect of edamame juice ratio with black mulbery juice and concentration of stabilizer to the characteristics of Edamuberry beverage. The Research consist of two stages : preminary research and main research. The main research conducted is to make Edamuberry beverage by using stabilizer that has been obtained form preliminary research. This research design was used factorial pattern $3 \times 3$ in Randomized Block Design (RBD), which consists of two factors. The ratio of edamame juice to black mulber $\quad y$ juice of three levels are 1:2, 1,5:1,5, 2:1 and concentration of stabilizer of three levels are $0,1 \%, 0,2 \%$ and $0,3 \%$. The response in the research was flavor, colour, taste, protein content of the kjedahl method, vitamin C content iodimetry method, and viscosity with viscometer. The result of preliminary research showed that Edamuberry beverage with additions CMC stabilizer prefered by consumers and have viscosity $145 \mathrm{mPas}$, stability $13,7^{\circ} \mathrm{Brix}$, and $\mathrm{pH} 5,9$. The result of main research were showed that : the ratio of edamame juice to black mulbery juice affected the colour, taste, protein content, vitamin $\mathrm{C}$ content and viscosity but does not affected flavor. CMC concentration affected the colour, taste and viscosity. The interaction ratio of edamame juice to black mulbery juice and CMC concentration affect to colour, taste and viscosity. The selected sample in the main research is a1b1 (ratio of edamame juice to black mulbery juice 1:2 and CMC concentration 0,1\%) with a protein content 3,301\%, vitamin $\mathrm{C}$ content $27,007 \mathrm{mg} / 100 \mathrm{~g}$ and viskosity 91,667 mPas.
\end{abstract}

Keywords: Edamame, Black Mulberry

\section{Pendahuluan}

Tingkat kesadaran masyarakat akan pentingnya menjaga kesehatan terhadap makanan sehat semakin meningkat. Berdasarkan data Nielsen's New Global Health and Ingredient-Sentiment Survey yang dirilis akhir 2016 mengenai pola konsumsi masyarakat modern di dunia menunjukkan bahwa $70 \%$ responden menjalani diet tertentu untuk menghindari berbagai penyakit degeneratif seperti obesitas, diabetes, kolesterol tinggi, dan hipertensi (Nielsen, 2016).

Selain itu, aktivitas dan tuntutan pekerjaan yang semakin meningkat membuat masyarakat terutama yang tinggal di perkotaan sulit untuk menjalani hidup sehat, ditambah dengan mengkonsumsi makanan cepat saji, kurangnya waktu olah raga, dan stres yang diakibatkan oleh pekerjaan tidak dapat dihindari. Oleh sebab itu minuman yang praktis dan bermanfaat akan memudahkan masyarakat dalam mengkonsumsinya (Adelia, 2018).

Inovasi terhadap pengolahan pangan merupakan cara alternatif mendapatkan produk olahan makanan atau minuman yang sehat, praktis, dan aman untuk dikonsumsi. Salah satunya adalah dengan pengolahan menggunakan bahan baku edamame. Edamame merupakan tanaman kedelai yang berasal dari Jepang yang telah berhasil dikembangkan di Indonesia. Tanaman ini merupakan komoditi unggul yang dikonsumsi sebagai kedelai segar (vegetables soybean), yaitu tanaman kedelai yang dipanen pada saat biji telah berkembang dan mengisi $80-90 \%$ ruang biji pada saat polong masih hijau segar (Suyono dan Susijohadi, 1994).

Menurut Grieshop et al., 2003 edamame termasuk kelompok makanan sehat (healthy food) karena mengandung komponen gizi yang kompleks yaitu, asam folat $482 \mathrm{mcg} / 100 \mathrm{~g}(121 \% \mathrm{AKG})$; protein $16.9 \mathrm{~g} / 100 \mathrm{~g}$ (34-45\% AKG), lemak 18-32\%, karbohidrat 12-30\%. Selain itu edamame mengandung vitamin A $100 \mathrm{mg}$; B1 0,27 mg; B2 0,14 mg; B3 $1 \mathrm{mg}$; dan vitamin C 27\%; serta mineral-mineral seperti fosfor $140 \mathrm{mg}$; kalsium $70 \mathrm{mg}$; besi $1,7 \mathrm{mg}$; dan kalium $140 \mathrm{mg}$ dalam $100 \mathrm{~g}$ edamame (Johnson, et al. 1999).

Pemanfaatan edamame menjadi produk olahan pangan sekarang ini masih relatif sedikit. Pada umumnya edamame dikonsumsi secara langsung setelah proses blanching atau diolah dalam bentuk frozen. Oleh karena itu perlu adanya diversifikasi produk olahan edamame, salah satunya adalah dengan mengolah edamame menjadi sari edamame.

Akan tetapi dalam pembuatan produk olahan edamame terdapat suatu hal yang paling dipermasalahkan yaitu edamame memiliki bau langu atau off flavor (disebabkan adanya enzim 
lipoksigenase), rasa pahit, dan rasa seperti kapur (Rahmawati dan Joni, 2017).

Berdasarkan hal tersebut pengembangan minuman sari edamame menjadi penting sehingga dapat menghasilkan minuman yang bisa diterima oleh masyarakat dari segi sensoriknya. Pengembangan dapat dilakukan dengan cara mengkombinasikan edamame dengan bahan pangan lain seperti black mulberry.

Rasa asam black mulberry dapat mengurangi rasa pahit dan rasa seperti kapur yang terdapat pada edamame, dan juga kadar air yang tinggi dapat menurunkan kekentalan yang terdapat pada edamame.

Buah black mulberry (Morus nigra L.) kaya akan vitamin, seperti vitamin B1, B2, dan C. Buah black mulberry diharapkan dapat meningkatkan nilai fungsional produk sehingga menjadi sumber antioksidan yang baik. Dilihat dari karakter fisiknya, black mulberry merupakan buah yang berasa segar, manis, berwarna merah hingga kehitaman, dan memiliki kadar antosianin hingga $1993 \mathrm{mg} / 100 \mathrm{~g}$ yang mana antosianin berperan sebagai sumber antioksidan (Astawan, 2008 dikutip dari Rahmasari dkk, 2014).

Antosianin adalah pewarna alami yang berasal dari familia flavonoid yang larut dalam air yang menimbulkan warna merah, biru, violet (Sartono, 2011).

Umumnya produk minuman campuran yang berada dipasaran memiliki kestabilan yang kurang baik, contohnya selama penyimpanan produk tersebut mengalami pengendapan, yaitu terjadi pemisahan antara cairan yang terdapat dalam minuman campuran tersebut. Untuk menghindari terjadinya pengendapan tersebut, maka ditambahkan bahan penstabil. Penstabil yang digunakan yaitu CMC dan gum arab.

Bahan penstabil seperti CMC (Carboxhy methyl Celullose) merupakan polielektrolik amonil turunan dari selullose yang digunakan secara luas dalam industri makanan. Bentuknya yang telah dimurnikan dan termasuk bahan untuk makanan sering disebut gum selullose (Ganz,1997, yang dikutip dari Fadila, 2017). Dalam industri pangan CMC ini berfungsi sebagai pengikat air, pengental, pengemulsi, dan stabilisator emulsi (Winarno, 2002). Gum arab (Acacia, gummy mimosae) adalah eksudat gum kering yang diperoleh dari batang dan bahan acacia senegal dan beberapa spesies acacia lainnya (Familia Leguminasae). (Tranggono, 1999).

Penambahan konsentrasi CMC yang berlebihan dapat meningkatkan viskositas larutan (Kamal, 2010). Selain itu, dengan menambahakan gum arab pada larutan, viskositas akan meningkat sebanding dengan peningkatan konsentrasi (Tranggono dkk, 1991).

\section{Bahan dan Metode Penelitian}

Bahan baku yang akan digunakan pada penelitian ini adalah edamame (Glycine max L. merril) yang didapatkan dari daerah Ngamprah, kabupaten Bandung Barat. Buah black mulberry (Morus nigra L.) yang diperoleh dari daerah Maribaya kabupaten Bandung
Barat. Gula , CMC dan Gum Arab dari toko PD. Kijang Mas dan air.

Bahan-bahan lain yang digunakan untuk analisis minuman Edamuberry adalah diantaranya larutan I2 baku 0,01 N, amilum, garam Kjedahl, H2SO4 pekat, aquadest, $\mathrm{NaOH} 1 \mathrm{~N}$.

Alat yang digunakan dalam pembuatan minuman Edamuberry adalah neraca digital, blender, kain waring, kompor gas, cup plastik, sendok, lemari pendingin, gelas ukur, dan toples.

Alat-alat yang digunakan untuk analisis diantaranya erlenmeyer, viskometer, gelas kimia, neraca digital, kompor gas, gelas ukur, tangkrus, filler, pipet tetes, glass beaker, klem dan statif labu bundar, destilator, labu takar, tabung erlenmeyer, pipet, buret, dan $\mathrm{pH}$ meter.

Pelaksanaan penelitian dalam pembuatan minuman Edamuberry ini terbagi dalam dua tahap, yaitu penelitian pendahuluan dan penelitian utama.

Penelitian pendahuluan ini dilakukan untuk mengetahui kadar protein pada sari edamame, kadar vitamin $\mathrm{C}$ pada sari black mulberry, serta uji viskositas dan uji total padatan terlarut pada minuman Edamuberry dengan penambahan jenis penstabil CMC dan Gum Arab kemudian menetapkan jenis bahan penstabil yang akan digunakan pada penelitian utama dengan uji organoleptik.

Analisis bahan baku yaitu sari edamame meliputi analisis kadar protein dengan metode Kjedahl, sari black mulberry meliputi analisis vitamin $\mathrm{C}$ dengan metode titrasi Iodimetri.

Selanjutnya, penentuan bahan penstabil dengan cara membandingkan penstabil yang akan digunakan dalam pembuatan minuman Edamuberry. Bahan penstabil yang akan dibandingkan adalah CMC dan gum arab. Parameter respon yang diuji meliputi uji viskositas, uji kestabilan serta uji organoleptik dengan metode uji hedonik terhadap aroma, warna dan rasa.

Uji hedonik dilakukan dengan tujuan untuk mengetahui tingkat kesukaan atau penerimaan panelis terhadap aroma, warna dan rasa. Pengujian dilakukan oleh 30 panelis.

Penelitian utama yang akan dilakukan merupakan kelanjutan dari penelitian pendahuluan, yang bertujuan untuk mengetahui perbandingan sari edamame dengan sari black mulberry dan konsentrasi penstabil yang disukai dalam menghasilkan minuman dengan karakteristik yang paling diterima oleh konsumen. Penelitian utama ini terdiri dari rancangan perlakuan, rancangan percobaan, rancangan analisis, rancangan respon,

Rancangan perlakuan penelitian utama minuman Edamuberry, perlakuan yang digunakan berdasarkan faktor sari edamame dengan sari black mulberry dan penambahan konsentrasi penstabil.

Faktor (A) perbandingan sari edamame dengan sari black mulberry yang digunakan adalah : 
a1 $=1: 2$

a2 $=1,5: 1,5$

a3 $=2: 1$

Faktor (B) konsentrasi penstabil yang digunakan adalah :

$$
\begin{aligned}
& \mathrm{b} 1=0,10 \% \\
& \mathrm{~b} 2=0,20 \% \\
& \mathrm{~b} 3=0,30 \%
\end{aligned}
$$

Model rancangan percobaan yang digunakan dalam penelitian ini adalah pola faktorial dalam Rancangan Acak Kelompok (RAK). Penelitian utama memiliki faktorial 3x3 dengan 3 kali ulangan, sehingga diperoleh 27 satuan percobaan. Respon pada penelitian utama yaitu Uji hedonik terhadap sampel minuman Edamuberry dilakukan dengan melibatkan 30 orang panelis dan diminta untuk memberikan penilaian terhadap warna, rasa, dan aroma untuk mengetahui tingkat kesukaan terhadap produk tersebut.Respon kimia yang diuji yaitu protein metode Kjedahl dan Vitamin C metode iodimetri (Sudarmaji, 2010). Respon fisik yang dilakukan terhadap produk minuman Edamuberry yaitu sifat fisik viskositas dengan viskometer (AOAC, 2005).

\section{Hasil dan Pembahasan \\ Penelitian Pendahuluan}

1. Analisis Bahan Baku

Hasil analisis bahan baku dapat dilihat pada Tabel 1.

Tabel 1. Data Hasil Analisis Bahan Baku

\begin{tabular}{|c|c|c|c|}
\hline Bahan Baku & Protein & Vitamin C & $\mathrm{pH}$ \\
\hline Sari Edamame & $5,41 \%$ & - & 7,1 \\
\hline Sari Black Mulberry & - & $33,46 \mathrm{mg} / 100 \mathrm{~g}$ & 3,5 \\
\hline
\end{tabular}

Penentuan jenis penstabil dilakukan dengan membuat minuman Edamuberry dengan perbanding sari edamame dan sari black mulberry 1,5:1,5 dan konsentrasi gula 9\%. Penstabil yang digunakan pada penelitian pendahuluan ini yaitu CMC sebanyak $0,2 \%$ dan gum arab $0,3 \%$. Pengujian yang dilakukan yaitu respon fisik (viskositas, $\mathrm{pH}$ dan TSS) dan respon organoleptik menggunakan uji hedonik (kesukaan) terhadap 30 panelis dengan atribut aroma, warna dan rasa.

Tabel 2. Data Hasil Analisis Sari Edamame dan Sari Black Mulberry dengan Penambahan Jenis Penstabil

\begin{tabular}{|c|c|c|c|}
\hline Sampel & Viskositas & pH & TSS \\
\hline $\begin{array}{c}\text { Sari Edamame + Sari Black } \\
\text { Mulberry }\end{array}$ & - & 5,2 & 8,6 \\
\hline $\begin{array}{c}\text { Sari Edamame + Sari Black } \\
\text { Mulberry + CMC }\end{array}$ & 145 mPas & 5,9 & 13,7 \\
\hline $\begin{array}{c}\text { Sari Edamame + Sari Black } \\
\text { Mulberry + Gum Arab }\end{array}$ & 105 mPas & 5,6 & 12,2 \\
\hline
\end{tabular}

Berdasarkan hasil analisis viskositas sari edamame dan sari black mulberry tidak terdeteksi hal ini dapat disebabkan karena sifak fisik dari bahan baku terlalu cair, sedangkan viskositas dari penambahan jenis penstabil CMC adalah $145 \mathrm{mPas}$ dan $\mathrm{pH}$ nya berupah menjadi 5,9 karena pada $\mathrm{pH} 5$ - 11 viskositas CMC stabil (Winarno, 2004). Sedangkan minuman Edamuberry dan penambahan jenis penstabil Gum Arab memiliki viskositas lebih rendah yaitu $105 \mathrm{mPas}$ dan $\mathrm{pH}$ 5,6 tidak sesuai dengan $\mathrm{pH}$ optimal Gum Arab yaitu pada suasana asam rentang $\mathrm{pH} 4,5-5,5$ (Minifie, 1989).

Selain viskositas, pada minuman Edamuberry juga dilakukan analisis total padatan terlarut dengan menggunakan hand refractometer. Pada minuman Edamuberry diperoleh hasil $8,6 \%$ sedangkan total padatan terlarut dari penambahan jenis penstabil CMC berubah menjadi $13,7 \%$ dan hasil dari penambahan jenis penstabil Gum Arab lebih rendah yaitu 12,2\%. Hal ini dikarekan kestabilan Gum Arab dalam mengikat partikel-partikel kurang baik jika dibandingkan dengan CMC.

Berdasarkan hasil analisis viskositas sari edamame dan sari black mulberry tidak terdeteksi hal ini dapat disebabkan karena sifak fisik dari bahan baku terlalu cair, sedangkan viskositas dari penambahan jenis penstabil CMC adalah $145 \mathrm{mPas}$ dan $\mathrm{pH}$ nya berupah menjadi 5,9 karena pada pH 5 - 11 viskositas CMC stabil (Winarno, 2004).

Sedangkan minuman Edamuberry dan penambahan jenis penstabil Gum Arab memiliki viskositas lebih rendah yaitu $105 \mathrm{mPas}$ dan $\mathrm{pH}$ 5,6 tidak sesuai dengan $\mathrm{pH}$ optimal Gum Arab yaitu pada suasana asam rentang pH 4,5 - 5,5 (Minifie, 1989).

Selain viskositas, pada minuman Edamuberry juga dilakukan analisis total padatan terlarut dengan menggunakan hand refractometer. Pada minuman Edamuberry diperoleh hasil $8,6 \%$ sedangkan total padatan terlarut dari penambahan jenis penstabil CMC berubah menjadi 13,7\% dan hasil dari penambahan jenis penstabil Gum Arab lebih rendah yaitu 12,2\%. Hal ini dikarekan kestabilan Gum Arab dalam mengikat partikel-partikel kurang baik jika dibandingkan dengan CMC.

Tabel 3. Data Hasil Organoleptik Sari Edamame dan Sari Black Mulberry dengan Penambahan Jenis Penstabil

\begin{tabular}{|c|c|c|c|}
\hline \multirow{2}{*}{$\begin{array}{c}\text { Jenis } \\
\text { Penstabil }\end{array}$} & \multicolumn{3}{|c|}{ Atribut } \\
\cline { 2 - 4 } & Aroma & Warna & Rasa \\
\hline (CMC) & $4,40^{\mathrm{a}}$ & $4,43^{\mathrm{a}}$ & $4,43^{\mathrm{a}}$ \\
\hline$(\mathrm{Gum} A r a b)$ & $4,17^{\mathrm{a}}$ & $4,40^{\mathrm{a}}$ & $4,30^{\mathrm{b}}$ \\
\hline
\end{tabular}

Keterangan : Rata-rata nilai kesukaan yang paling tinggi menunjukkan sampel yang paling disukai oleh panelis

Data Tabel 3, menunjukkan bahwa hasil pengamatan uji organoleptik terhadap atribut aroma, warna, dan rasa yang paling banyak disukai oleh panelis yaitu jenis bahan penstabil CMC karena mendapatkan nilai rata-rata paling besar dibandingkan dengan Gum Arab. Menurut penelitian Nasrullah (2011), jenis bahan penstabil yang baik pada pembuatan minuman sari kacang kedelai campuran buah yaitu CMC yang 
memiliki warna serbuk putih dan tidak berbau sehingga tidak memperngaruhi warna dan aroma dari susu kedelai campuran buah.

CMC banyak digunakan sebagai penstabil (stabilizer) pada es krim, sari buah, sorbet, susu, roti, bahan pengoles kue, salad dressing, mayonnaise, jelly, dan jam (Glicksman, 1984). Kekentalan larutan CMC dipengaruhi oleh $\mathrm{pH}$, suhu, konsentrasi, garam dan gelatin. Pengasaman dibawah $\mathrm{pH}$ 5,0 dapat menurunkan kekentalan sedangkan pada $\mathrm{pH}$ dibawah 3,0 akan terjadi pengendapan asam karboksimetil selulose bebas. Bila dipanaskan maka kekentalan larutan CMC akan turun (Ganz, 1977).

Penurunan kekentalan ini disebabkan oleh terjadinya kenaikan energi panas sehingga ikatan hidrogen pecah dan akibatnya air yang terikat pada rantai polimer menjadi lebih sedikit. Kenaikan konsentrasi CMC dalam larutan dapat mengakibatkan kenaikan kekentalan (Ganz, 1977).

\section{Hasil Penelitian Utama}

1. Uji Organoleptik

a. Aroma

Berdasarkan hasil analisis variansi (ANAVA) pada Lampiran 8. yang dilakukan pada produk minuman Edamuberry dapat diketahui bahwa perbandingan sari edamame dengan sari black mulberry (A), konsentrasi penstabil (B), dan interaksi antara kedua faktor (AB) tidak berpengaruh nyata terhadap aroma minuman Edamuberry sehingga tidak diperlukan uji lanjut Duncan.

Dalam hal atribut aroma tidak ada perbedaan yang nyata dalam setiap perlakuan meskipun pada kenyataannya aroma dari setiap perlakuan berbedabeda. Hal ini dapat terjadi karena sebelumnya edamame telah mengalami proses blanching dan penghancuran menggunakan air panas $(\mathrm{T}=80 \mathrm{oC})$ sehingga bau langu pada sari edamame berkurang selain itu dengan penambahan sari black mulberry juga dapat mengurangi bau langu pada sari edamame karena black mulberry sendiri memiliki bau tersendiri sehingga panelis menjadi tidak mempermasalahkan aroma dari minuman Edamuberry.

Tidak adanya pengaruh nyata dan interaksi bisa disebabkan panelis mempunyai penilaian yang hampir sama terhadap aroma dari minuman Edamuberry tersebut karena bau langu yang menjadi masalah dalam produk olahan edamame sudah diatasi dengan cara pemanasan.

Aroma merupakan salah satu parameter identifikasi flavor yang paling mudah dan paling sering dilakukan. Aroma dapat didefinisikan sebagai sesuatu yang dapat diamati dengan indera penciuman. Aroma yang tercium dapat diukur sehingga biasanya menimbulkan pendapat yang berlainan dalam menilai kualitas aromanya. Perbedaan pendapat dapat disebabkan karena tiap orang memiliki perbedaan penciuman, meskipun mereka dapat membedakan aroma namun setiap orang mempunyai kesukaan yang berlainan (Kartika, dkk., 1988).

\section{b. Warna}

Berdasarkan hasil analisis variansi (ANAVA) pada Lampiran 9. yang dilakukan pada produk minuman Edamuberry dapat diketahui bahwa perbandingan sari edamame dengan sari black mulberry (A), konsentrasi penstabil (B), dan interaksi antara keduanya (AB) berpengaruh nyata terhadap warna minuman Edamuberry sehingga perlu dilakukan uji lanjut Duncan.

Tabel 4. Pengaruh Interaksi Perbandingan Sari Edamame dengan Sari Black Mulberry dan Konsentrasi Penstabil terhadap Warna Minuman Edamuberry

\begin{tabular}{|c|c|c|c|}
\hline \multirow{2}{*}{$\begin{array}{l}\text { Perbandingan Sari } \\
\text { Edamame dengan Sari } \\
\text { Black Mulberry (A) }\end{array}$} & \multicolumn{3}{|c|}{ Konsentrasi Penstabil (B) } \\
\hline & b1 $(0,1 \%)$ & b2 $(0,1 \%)$ & b3 $(0,1 \%)$ \\
\hline a1 $(1: 2)$ & ${ }_{b} 5.18^{\mathrm{B}}$ & $\mathrm{b}^{\mathrm{A}}$ & $a^{2}{ }^{\mathrm{A}}$ \\
\hline a2 $(1,5: 1,5)$ & $\begin{array}{l}\mathrm{A} \\
\mathrm{a}\end{array}$ & $\begin{array}{l}\mathrm{A} \\
\mathrm{a}\end{array}$ & $\mathrm{a} \quad 3.98^{\mathrm{A}}$ \\
\hline a3 $(2: 1)$ & $\begin{array}{l}\mathrm{A} \\
\mathrm{a} \quad 4.20^{2}\end{array}$ & ${ }_{\mathrm{a}}{ }^{4.06^{\mathrm{A}}}$ & $\mathrm{a} \quad 3.52^{\mathrm{A}}$ \\
\hline
\end{tabular}

Keterangan : Nilai rata-rata perlakuan yang ditandai notasi huruf yang berbeda menunjukkan perbedaan yang nyata menurut uji lanjut Duncan pada taraf nyata 5\%. Huruf kapital dibaca vertikal. Huruf kecil dibaca horizontal.

Data pada Tabel 14, menunjukkan bahwa semakin meningkatnya penambahan sari black mulberry terjadi peningkatan nilai kesukaan panelis. Hal ini disebabkan karena warna yang dihasilkan pada semua formulasi secara keseluruhan didominasi oleh pigmen warna ungu yang terdapat pada sari black mulberry yaitu antosianin, sedangkan pigmen warna hijau yang berasal dari sari edamame yaitu flavonoid dan klorofil tidak memberikan pengaruh yang begitu nyata terhadap produk akhir minuman Edamuberry yaitu ungu pudar sampai ungu pekat.

Konsentrasi penstabil berpengaruh terhadap warna karena semakin tinggi konsentrasi bahan penstabil yang ditambahkan, maka kadar air dari minuman Edamuberry akan mempunyai gambaran semakin rendah dan viskositas semakin tinggi. Apabila viskositas larutan menjadi tinggi, maka warna pun berubah menjadi lebih gelap. Sehingga mempengaruhi warna dari minuman Edamuberry tersebut.

Warna bukan merupakan suatu zat atau benda melainkan suatu sensasi seseorang oleh karena adanya rangsangan dari seberkas energi radiasi yang jatuh ke indera atau retina mata. Timbulnya warna dibatasi oleh faktor terdapatnya sumber sinar (Kartika, dkk., 1988).

Penerimaan warna suatu makanan berbeda-beda tergantung pada faktor geografis, aspek sosial dan faktor alam. Secara visual faktor warna tampil lebih dulu dan sangat menentukan. Suatu makanan yang bernilai gizi, 
enak, dan teksturnya baik tidak akan menarik apabila tidak memiliki warna yang sedap dipandang (Winarno, 1997).

\section{c. Rasa}

Berdasarkan hasil analisis variansi (ANAVA) pada Lampiran 9. yang dilakukan pada produk minuman Edamuberry dapat diketahui bahwa perbandingan sari edamame dengan sari black mulberry (A), konsentrasi penstabil (B), dan interaksi antara perbandingan sari edamame dengan sari black mulberry dan konsentrasi penstabil (AB) berpengaruh nyata terhadap rasa minuman Edamuberry sehingga diperlukan uji lanjut Duncan.

Tabel 5. Pengaruh Interaksi Perbandingan Sari Edamame dengan Sari Black Mulberry dan Konsentrasi Penstabil terhadap Rasa Minuman Edamuberry

\begin{tabular}{|c|c|c|c|}
\hline \multirow{2}{*}{$\begin{array}{l}\text { Perbandingan Sari } \\
\text { Edamame dengan Sari } \\
\text { Black Mulberry (A) }\end{array}$} & \multicolumn{3}{|c|}{ Konsentrasi Penstabil (B) } \\
\hline & b1 $(0,1 \%)$ & b2 $(0,1 \%)$ & b3 $(0,1 \%)$ \\
\hline a1 $(1: 2)$ & ${ }_{c}{ }^{\mathrm{C}}$ & ${ }^{b}{ }^{\mathrm{B}}$ & $\mathrm{A}^{\mathrm{C}}$ \\
\hline a2 $(1,5: 1,5)$ & c $4.83^{\mathrm{B}}$ & $\mathrm{b}^{\mathrm{A}}$ & $\mathrm{A}^{3.86^{\mathrm{B}}}$ \\
\hline a3 $(2: 1)$ & c $4.67^{\mathrm{A}}$ & $\mathrm{b}^{\mathrm{A}}{ }^{\mathrm{A}}$ & $\mathrm{A}^{3.46^{\mathrm{A}}}$ \\
\hline
\end{tabular}

Keterangan : Nilai rata-rata perlakuan yang ditandai notasi huruf yang berbeda menunjukkan perbedaan yang nyata menurut uji lanjut Duncan pada taraf nyata $5 \%$. Huruf kapital dibaca vertikal. Huruf kecil dibaca horizontal

Data pada Tabel 15, menunjukkan bahwa semakin meningkatnya perbandingan sari black mulberry dan semakin kecil konsentrasi penstabil yang digunakan terjadi peningkatan nilai kesukaan panelis terhadap rasa.

Penambahan perbandingan sari black mulberry yang banyak dapat memberikan pengaruh terhadap rasa minuman Edamuberry. Hal ini disebabkan karena buah black mulberry cenderung memiliki rasa yang manis sedikit asam sehingga dapat menambah cita rasa dari minuman Edamuberry. Perbedaan penambahan sari black mulberry. Hal tersebut sesuai dengan pendapat Ulfah (2016) yang menyatakan bahwa perbedaan penambahan sari black mulberry dapat mempengaruhi perbedaan rasa pada setiap perlakuan.

Perbedaan tingkat kesukaan terhadap rasa minuman Edamuberry juga dipengaruhi oleh penambahan konsentrasi penstabil yang mengakibatkan peningkatan konsistensi sehingga berpengaruh terhadap rasa. Semakin banyak konsentrasi CMC yang ditambahkan maka akan menurunkan tingkat kesukaan panelis terhadap minuman Edamuberry. Hal tersebut sesuai dengan pernyataan Harun (2013) yang menyatakan penggunaan bahan penstabil pada produk minuman yang berlebihan dan konsentrasi yang tidak tepat akan menciptakan suatu produk minuman tidak disukai oleh konsumen.
Rasa dalam bahan pangan sangat penting dalam menentukan daya terima konsumen. Selain itu rasa juga merupakan salah satu faktor yang sangat berpengaruh dalam menentukan mutu. Biasanya rasa sangat diperhatikan oleh konsumen setelah warna (deMan, 1997). Rasa dipengaruhi oleh beberapa faktor, yaitu senyawa kimia, suhu, konsentrasi dan interaksi dengan komponen rasa yang lainnya.

Instrumen yang paling berperan mengetahui rasa suatu bahan pangan adalah indera pengecap (lidah). Rasa makanan biasanya dapat dikenali dan dibedakan oleh kuncup-kuncup cecapan yang terletak pada papila yaitu bagian noda merah jingga pada lidah. Dalam pengawasan mutu makanan, rasa termasuk komponen yang sangat penting untuk menentukan penerimaan konsumen (Winarno, 1993).

\section{Protein}

Berdasarkan hasil perhitungan analisis ragam (ANAVA) terhadap kadar protein (\%) yang tercantum pada Lampiran 10. dapat diketahui bahwa perbandingan sari edamame dengan sari black mulberry (A) berpengaruh nyata terhadap minuman Edamuberry, sedangkan konsentrasi penstabil (B) dan interaksi perbandingan sari edamame dengan sari black mulberry dan konsentrasi penstabil (AB) tidak berpengaruh nyata sehingga tidak perlu dilakukan uji lanjut Duncan.

Tabel 6. Pengaruh Perbandingan Sari Edamame dengan Sari Black Mulberry (A) Terhadap Kadar Protein (\%) Minuman Edamuberry

\begin{tabular}{|c|c|c|}
\hline $\begin{array}{c}\text { Perbandingan Sari } \\
\text { Edamame dengan Sari } \\
\text { Black Mulberry (A) }\end{array}$ & Nilai Rata-rata & $\begin{array}{c}\text { Taraf } \\
\text { Nyata } \\
\mathbf{5 \%}\end{array}$ \\
\hline A1 $(1: 2)$ & $3,28 \%$ & $\mathrm{a}$ \\
\hline A2 $(1,5: 1,5)$ & $3,83 \%$ & $\mathrm{~b}$ \\
\hline A3 $(2: 1)$ & $4,37 \%$ & $\mathrm{c}$ \\
\hline
\end{tabular}

Keterangan : Nilai rata-rata yang ditandai dengan menggunakan huruf yang sama menunjukkan bahwa perlakuan tidak berbeda nyata pada taraf 5\% menurut uji Duncan dan jika ditandai dengan huruf yang tidak sama menunjukkan perbedaan nyata pada taraf $5 \%$ menurut uji Duncan

Data pada Tabel 6, menunjukkan bahwa semakin tinggi perbandingan sari edamame yang ditambahkan, maka kadar protein minuman Edamuberry yang dihasilkan semakin tinggi. Konsentrasi penstabil tidak memberikan pengaruh yang nyata terhadap kadar protein karena dalam jenis penstabil CMC tidak mengandung kadar protein yang signifikan sehingga tidak terjadi interaksi antara kedua faktor tersebut.

Sumber protein yang terkandung dalam minuman Edamuberry ini berasal dari bahan baku yang digunakan yaitu sari edamame. Berdasarkan penelitian pendahuluan (Tabel 11), kandungan protein pada sari edamame adalah $5,412 \%$. Terjadi penurunan kadar protein dari bahan sari edamame hingga menjadi produk minuman Edamuberry, hal ini disebabkan karena pada pembuatan minuman Edamuberry terdapat proses pasteurisasi sehingga sangat memungkinkan terjadinya penurunan kadar protein. 
Protein merupakan suatu zat makanan yang amat penting bagi tubuh, karena zat ini disamping berfungsi sebagai bahan bakar dalam tubuh juga berfungsi sebagai zat pembangun dan pengatur (Winarno, 1992).

\section{Vitamin C}

Berdasarkan hasil analisis variansi (ANAVA) terhadap kadar vitamin C (mg/100g) yang tercantum pada Lampiran 10. dapat diketahui bahwa perbandingan sari edamame dengan sari black mulberry (A) berpengaruh nyata terhadap minuman Edamuberry, sedangkan konsentrasi penstabil (B) dan interaksi perbandingan sari edamame dengan sari black mulberry dan konsentrasi penstabil (AB) tidak berpengaruh nyata sehingga tidak perlu dilakukan uji lanjut Duncan.

Tabel 7. Pengaruh Perbandingan Sari Edamame dengan Sari Black Mulberry (A) terhadap Kadar Vitamin C (mg/100g) Minuman Edamuberry

\begin{tabular}{|c|c|c|}
\hline $\begin{array}{c}\text { Perbandingan Sari } \\
\text { Edamame dengan Sari } \\
\text { Black Mulberry (A) }\end{array}$ & Nilai Rata-rata & $\begin{array}{c}\text { Taraf Nyata } \\
\mathbf{5 \%}\end{array}$ \\
\hline $\mathrm{A} 1(1: 2)$ & $27,99 \mathrm{mg} / 100 \mathrm{~g}$ & $\mathrm{c}$ \\
\hline $\mathrm{A} 2(1,5: 1,5)$ & $23,66 \mathrm{mg} / 100 \mathrm{~g}$ & $\mathrm{~b}$ \\
\hline $\mathrm{A} 3(2: 1)$ & $15,01 \mathrm{mg} / 100 \mathrm{~g}$ & $\mathrm{a}$ \\
\hline
\end{tabular}

Keterangan : Nilai rata-rata yang ditandai dengan menggunakan huruf yang sama menunjukkan bahwa perlakuan tidak berbeda nyata pada taraf 5\% menurut uji Duncan dan jika ditandai dengan huruf yang tidak sama menunjukkan perbedaan nyata pada taraf 5\% menurut uji Duncan

Data pada Tabel 7, menunjukkan bahwa semakin rendah penggunaan sari edamame dan semakin tinggi penggunaan sari black mulberry, kandungan vitamin $\mathrm{C}$ pada minuman Edamuberry semakin tinggi yang didapat. Hal tersebut disebabkan karena kandungan vitamin C pada sari black mulberry lebih tinggi dibandingkan dengan kandungan vitamin $\mathrm{C}$ pada sari edamame.

Menurut United State Department of Agricultural Food (2018), kandungan vitamin C dalam edamame segar sebesar 6,1 mg/100 g dimana kandungan vitamin $\mathrm{C}$ yang dimiliki edamame ini lebih rendah dibandingkan dengan kandungan vitamin $\mathrm{C}$ pada sari black mulberry sebesar 33,465 mg/100 g, oleh karena itu semakin tinggi penggunaan sari black mulberry dan semakin rendah penggunaan sari edamame maka kandungan vitamin $\mathrm{C}$ pada minuman Edamuberry akan semakin tinggi.

Pada hasil analisis kadar vitamin $\mathrm{C}$ minuman Edamuberry terjadi penurunan kadar vitamin C. Hal tersebut dapat terjadi karena vitamin $\mathrm{C}$ memiliki sifat yang mudah rusak dan pada proses pembuatan minuman Edamuberry terjadi proses pasteurisasi pada suhu $80 \mathrm{oC}$ selama 15 menit.

Vitamin C merupakan jenis vitamin yang mudah rusak. Disamping mudah larut dalam air, vitamin $\mathrm{C}$ juga mudah teroksidasi dan proses tersebut dipercepat oleh panas, sinar, alkali, oksigen, serta oleh katalis tembaga dan besi. Vitamin C tidak dapat diproduksi oleh tubuh, sehingga untuk memenuhi kebutuhan vitamin $\mathrm{C}$ dapat dilakukan dengan cara mengkonsumsi buah-buahan dan sayuran, yang merupakan sumber vitamin C yang cukup baik (Winarno, 2004). Menurut Hulme (1997) dikutip dari Shaumi (2014), asam askorbat dan garam natriumnya sangat stabil dalam keadaan tanpa air, tetapi dalam keadaan ada air dan oksigen atau bahan pengoksidasi lainnya maka asam askorbat menjadi tidak stabil. Vitamin C menurut Hermawan (2016), mudah teroksidasi pada $\mathrm{pH}$ basa karena sifat dari vitamin $\mathrm{C}$ yang tidak dapat bertahan pada $\mathrm{pH}$ yang basa, dimana vitamin $\mathrm{C}$ akan bertahan dengan baik jika berada pada $\mathrm{pH}$ yang asam.

\section{Viskositas}

Perbandingan sari edamame dengan sari black mulberry (A), konsentrasi penstabil (B), dan interaksi antara perbandingan sari edamame dengan sari black mulberry dan konsentrasi penstabil (AB) berpengaruh nyata terhadap viskositas minuman Edamuberry sehingga perlu dilakukan uji lanjut Duncan. Pengaruh interaksi antara faktor A dan faktor B dapat dilihat pada Tabel 8.

Tabel 8. Pengaruh Interaksi Perbandingan Sari Edamame dengan Sari Black Mulberry dan Konsentrasi Penstabil terhadap Viskositas Minuman Edamuberry

\begin{tabular}{|c|c|c|c|}
\hline \multirow{2}{*}{$\begin{array}{c}\text { Perbandingan Sari } \\
\text { Edamame dengan Sari } \\
\text { Black Mulberry (A) }\end{array}$} & \multicolumn{3}{|c|}{ Konsentrasi Penstabil (B) } \\
\hline & b1 $(0,1 \%)$ & b2 $(0,2 \%)$ & b3 $(0,3 \%)$ \\
\hline a1 $(1: 2)$ & $\mathrm{a} 91,67^{\mathrm{C}}$ & ${ }_{\mathrm{b}}{ }^{\mathrm{B}}$ & c ${ }^{186,67^{B}}$ \\
\hline a2 $(1,5: 1,5)$ & $\begin{array}{l}\mathrm{a} \quad 83,33 \\
\end{array}$ & $\mathrm{~b}^{\mathrm{A}}{ }^{\mathrm{A}}$ & $\begin{array}{l}\mathrm{c} \quad 181,67 \\
\mathrm{c}\end{array}$ \\
\hline a3 $(2: 1)$ & $\begin{array}{l}\mathrm{A} \\
\mathrm{a}\end{array}$ & $\mathrm{b}^{\mathrm{A}}$ & $\begin{array}{l}\mathrm{c}{ }^{\mathrm{A}} \\
\mathrm{c}\end{array}$ \\
\hline
\end{tabular}

Keterangan : Nilai rata-rata perlakuan yang ditandai notasi huruf yang berbeda menunjukkan perbedaan yang nyata menurut uji lanjut Duncan pada taraf nyata 5\%. Huruf kapital dibaca vertikal. Huruf kecil dibaca horizontal.

Berdasarkan hasil uji lanjut Duncan pada Tabel 8 . menunjukkan bahwa semakin meningkatnya konsentrasi penstabil dengan perbandingan sari edamame dan sari black mulberry yang tetap terjadi peningkatan nilai viskositas. Hal tersebut disebabkan karena semakin bertambahnya konsentrasi CMC sebagai bahan penstabil maka akan menyebabkan bobot molekul yang terdapat dalam minuman Edamuberry semakin bertambah, sehingga dapat meningkatkan nilai viskositas minuman Edamuberry. Hal ini sependapat dengan Rini dkk (2012), yang menyatakan bahwa kenaikan pemberian konsentrasi CMC dalam larutan dapat mengakibatkan banyaknya air yang terikat, dengan meningkatnya air yang terikat, maka semakin besar kenaikan viskositas.

Menurut Siskawardhani, dkk (2013), yang menyatakan bahwa mekanisme kerja CMC sebagai 
stabilisator emulsi berhubungan erat dengan kemampuannya yang sangat tinggi dalam mengikat air, sehingga meningkatkan viskositas larutan, dimana butirbutir CMC bersfifat berikatan dengan air sehingga akan menyerap air dan akhirnya membengkak. Air yang sebelumnya berada di luar granula dan bebas akan bergerak lagi, sehingga keadaan larutan menjadi lebih mantap dan terjadi peningkatan viskositas.

5. Produk Terpilih

Berdasarkan hasil metode skoring sampel yang terpilih adalah perlakuan a1b1 dengan perbandingan sari edamame dan sari black mulberry $1: 2$ serta konsentrasi penstabil $0,1 \%$ merupakan sampel yang paling disukai panelis karena memiliki nilai rata-rata kesukaan tertinggi dalam hal atribut aroma, warna dan rasa dengan kriteria "suka".

Tabel 9. Hasil Penentuan Sampel Terpilih Berdasarkan Metode Skoring

\begin{tabular}{|c|c|c|c|c|}
\hline \multirow{2}{*}{ Kode Sampel } & \multicolumn{3}{|c|}{ Respon Organoleptik } & \multirow{2}{*}{ Total } \\
\cline { 2 - 4 } & Aroma & Warna & Rasa & \\
\hline $\mathrm{a} 1 \mathrm{~b} 1$ & 4 & 5 & 5 & 14 \\
\hline $\mathrm{a} 1 \mathrm{~b} 2$ & 1 & 4 & 3 & 8 \\
\hline $\mathrm{a} 1 \mathrm{~b} 3$ & 5 & 1 & 3 & 9 \\
\hline $\mathrm{a} 2 \mathrm{~b} 1$ & 4 & 3 & 5 & 12 \\
\hline $\mathrm{a} 2 \mathrm{~b} 2$ & 2 & 3 & 3 & 8 \\
\hline $\mathrm{a} 2 \mathrm{~b} 3$ & 2 & 2 & 2 & 6 \\
\hline $\mathrm{a} 3 \mathrm{~b} 1$ & 3 & 3 & 4 & 10 \\
\hline $\mathrm{a} 3 \mathrm{~b} 2$ & 1 & 2 & 2 & 5 \\
\hline $\mathrm{a} 3 \mathrm{~b} 3$ & 1 & 1 & 1 & 3 \\
\hline
\end{tabular}

Penentuan produk yang dipilih mengacu pada karakteristik minuman Edamuberry yang diinginkan yaitu berdasarkan uji organoleptik dengan metode hedonik (uji penerimaan) dikarenakan salah satu karakteristik minuman Edamuberry yang diinginkan yaitu memiliki daya terima yang baik dalam hal sensorisnya.

Menurut Cahyadi (2012), jika pangan tidak diterima secara estetika, pangan tidak mendapat kesempatan untuk berperan pada pemenuhan kebutuhan gizi seseorang. Perlakuan alb1 memiliki kadar protein sebesar 3,301\%, kadar vitamin C 27,007 mg/100 g bahan dan viskositas 91,667 mPas.

Berdasarkan hasil penelitian, dapat diambil kesimpulan sebagai berikut.

1. Berdasarkan hasil analisis bahan baku sari edamame memiliki kadar protein sebesar 5,412\% dan $\mathrm{pH} 7,1$. Sari black mulberry memiliki kadar vitamin C sebesar 33,465 mg/100 g bahan dan $\mathrm{pH} 3,5$.

2. Pada penelitian pendahuluan penentuan bahan penstabil berdasarkan uji organoleptik (aroma, warna dan rasa), uji viskositas dan uji total padatan terlarut maka sampel yang terpilih yaitu sampel minuman Edamuberry dengan penambahan jenis penstabil CMC.

3. Pada penelitian utama menunjukkan bahwa perbandingan sari edamame dengan sari black mulberry berpengaruh nyata terhadap warna, rasa, kadar protein, kadar vitamin $\mathrm{C}$ dan viskositas. Sedangkan konsentrasi penstabil (CMC) berpengaruh terhadap warna, rasa dan viskositas.

4. Interaksi antara perbandingan sari edamame dengan sari black mulberry dan konsentrasi penstabil (CMC) berpengaruh terhadap warna, rasa dan viskositas.

5. Hasil penelitian utama produk minuman Edamuberry yang dipilih secara respon organoleptik adalah perlakuan a1b1, karena dilihat dari uji organoleptik merupakan sampel yang paling disukai oleh panelis dengan kadar protein sebesar 3,301\%, kadar vitamin C 27,007 mg/100g bahan dan viskositas 91,667 mPas.

\section{Daftar Pustaka}

1. Adelia, D. 2018. Optimalisasi Formulasi Mix Juice (Berryamun) Black Mulberry, Pepaya, dan Mentimun Menggunakan Design Expert Metode D-Optimal. Skripsi. Program Studi Teknologi Pangan. Fakultas Teknik Universitas Pasundan Bandung.

2. Association od Official Analytical Chemist (AOAC). 2005. Official Method of Analysis of Association of Official Analytical Chemist. Ed. 14. Benjamin Franklin Station. Washington.

3. Cahyadi, W. 2012. Analisis dan Aspek Kesehatan Bahan Tambahan Pangan. edisi ke-2. Bumi Aksara. Jakarta.

4. Ganz, A. J. 1997. Cellulosa Hydrocolloid. Avi Publishing Co. Inc. Westport. Connectiont

5. Harun, N., Rahmayuni dan Yucha, E., S. 2013. Penambahan Gula Kelapa dan Lama Fermentasi Terhadap Kualitas Susu Fermentasi Kacang Merah (Phaesolus vulgaris L.). Jurnal. Teknologi Hasil Pertanian. Universitas Riau. Pekanbaru.

6. Hermawan, S. 2016. Kajian Perbandingan Stoberi dengan Ekstrak Jahe dan Konsentrasi Penstabil Terhadap Karakteristik Minuman Fungsional Stroberi Jahe. Skripsi. Teknologi Pangan. Universitas Pasundan. Bandung.

7. Johnson D., Shaoke, Wang., and Akio, S. 1999. Edamame : A Vegetable Soybean for Colorado. p. 385-387. In: J. Janick (ed.), Perspectives on new crops and new uses. ASHS Press. Alexandria. VA.

8. Kartika, B., Hastuti, P., dan Supartono, P. 1988. Pedoman Uji Inderawi Bahan Pangan Yogyakarta: Pusat Antar Universitas Pangan dan Gizi.

9. Minifie, B. W. 1989. Chocolate, Cocoa and Confectionery. Van Coostrad Reinhold. New York.

10. Nasrullah, M. 2011. Kajian Jenis Buah dan Penstabil Terhadap Karakteristik Susu Kedelai (Glycine $\max$ L. Merril). Skripsi. Teknologi 
Pangan. Fakultas Teknik. Universitas Pasundan. Bandung.

11. Rahmawati, D. dan Joni, K. 2017. Penambahan Sari Buah Murbei (Morus alba L.) dan Gelatin Terhadap Karakteristik Fisiko-Kimia dan Mikrobiologi Yoghurt Susu. Jurnal Pangan dan Agroindustri. Vol. 5 No.3:83-94.

12. Sartono, M. 2011. Pengaruh Perbedaan Proporsi Ekstrak Black Mulberry dan Susu UHT serta Lama Penyimpanan Terhadap Warna dan Kadar Antosianin Yoghurt Mulberry. Universitas Katolik Widya Mandala. Surabaya.

13. Shaumi, N. L. 2014. Kajian Minuman Herbal Sari Buah Belimbing Yang Disubstitusi Ekstrak Kulit Manggis, Ekstrak Daun Sirsak, dan Ekstrak Sarang Semut. Skripsi. Program Studi Teknologi Pangan. Fakultas Teknik. Universitas Pasundan. Bandung.

14. Siskawardani, D., D., K. Nur dan B., H. Mohammad. 2013. Pengaruh Konsentrasi NaCmc (Natrium-Carboxymethyle Cellulose) dan Lama Sentrifugasi terhadap Sifat Fisik Kimia Minuman Asam Sari Tebu (Saccharum officinarum L.). Jurusan Keteknikan Pertanian. Fakultas Teknologi Pertanian. Universitas Brawijaya. Malang.

15. Soekarto, E. 1985. Penilaian Organoleptik untuk Industri Pangan dan Hasil Pertanian. Penerbit Bintara Karya Aksara. Jakarta.

16. Sudarmadji, S., B. Haryono, dan Suhardi. 2010. Analisis Bahan Makanan dan Pertanian. Liberty. Yogyakarta.

17. Suyono dan Susijohadi. 1994. Bercocok Tanam Edamame (Vegetable Soybean). Fakultas Pertanian. Universitas Jember.

18. Tranggono. 1988. Biokimia dan Fisiologi Karbohidrat. Pusat Antar Universitas Pangan dan Gizi. Universitas Gadjah Mada. Yogyakarta.

19. United State Department of Agriculture (USDA). 2018. Edamame, Frozen, Prepared.http://ndb.nal.usda.gov./ndb/foods/show/1 1212?n1=\%7BQv\%3D1\%7D\&man $=\& 1$ facet $=\&$ co unt $=\& \max =25 \&$ short $=$ default \&qlookup $=11212 \&$ of fset $=\&$ format $=$ full $\&$ new $=\&$ measureby $=\& Q v=1 \& d s$ $=\& \mathrm{q}=\& \mathrm{qp}=\& \mathrm{q} a=\& \mathrm{qn}=\& \mathrm{q}=\& i n g=$. Diakses $: 3$ Agustus 2018

20. Winarno, F. G. 2004. Kimia Pangan dan Gizi. Jakarta : PT. Gramedia Pustaka Utama. 